\title{
A PORTRAIT OF SHARIA BUSINESS SYMBOLIZATION AND ITS SOLUTIONS
}

\author{
Wahidullah1, Jumaiyah 2 \\ 1, 2 Universitas Islam Nahdlatul Ulama Jepara \\ Email:1wahidullah@unisnu.ac.id,2mayawahidah@unisnu.ac.id
}

\begin{abstract}
The purpose of this study is to determine whether the knockout arisan money system is in accordance with sharia principles or not. The research method used is a qualitative descriptive method by observing, interviewing, and collecting documents as supporting data of KSPPS BMT Lumbung Artho Jepara Central Java Indonesia that implements the Yad Dhamanah Wadi'ah contract with the explanation that the stored assets or items can be used by aid providers and can also distribute to its members. However, the agreement is not in accordance with the fatwa of the National Sharia Council of Indonesian Majlis Ulama about the nature of Wadi'ah saving that deposits can be withdrawn according to the wishes of the depositors and not waiting for lottery numbers to take their deposits. Furthermore, the application of the bonus giving also deviates from the voluntary Wadi'ah contract and the bonus agreement at the beginning of the contract. However, because the practice of knockout arisan money system has already existed in the community, therefore the solution for its implementation is by using the agreement of the al-qardh (debt-receivable) and Mudharabah (profit-sharing) contracts that are closer to Islamic principles.
\end{abstract}

Keywords: Money Arisan, Falling Systems, Islamic Principles, Culture

\section{INTRODUCTION}

Arisan is a form of cooperation that is given a sum of money and then drawn to determine who can withdraw the funds and then can receive it. At the next time that has been mutually agreed upon then drawn again and still have to deposit some money but those who have already obtained some money cannot take funds.

And so on until all members of the gathering have received a turn in obtaining arisan funds. In the practice of the knockout arisan money system in KSPPS BMT Lumbung Artho is to use the Wadi'ah contract. In Islam, it is known as the principle of al-wadi'ah, which means that it is a pure deposit from one party to another which must be guarded and returned whenever the requester wishes.1 In the Qur'an and Hadith explained, (Republik and Departemen 2015)"Verily Allah tells you to deliver the message (entrusted) to those who are entitled to receive it." (HR Abu Daud) Rasulullah SAW said " Convey the message to those who have the right to receive it and do not repay treason to those who have betrayed you"

\footnotetext{
${ }^{1}$ Sehani. "Analisis Persepsi dan Preferensi Masyarakat Pesantren Terhadap Bank Syari'ah (studi pada Masyarakat Pesantren D Kota Pekanbaru )." Jurnal Al-Iqtishad, 2017 : 1-18
}

Website: http://jurnal.radenfatah..ac.id/index.php/ieconomics 
Basically, the recipient of the deposit is yad al-amanah which means that is responsible for what is mandated. But he is not responsible for the loss or damage that occurs on the assets deposited as long as this is not the result of negligence or carelessness of those concerned in maintaining the item deposited due to factors beyond the ability.2 But in the current economic activity, the recipient of the savings may not let these assets, but use them in certain economic activities. Therefore he must ask permission from the depositor in advance to use the assets, provided he guarantees that the asset will return in full. Therefore, he is no longer yad al-amanah but yad aldhomanah, which is responsible for any loss or damage to the asset. 3

Wadi'ah yad Al-dhomanah, The goods deposited can usually be in the form of goods or assets that can produce benefits, even though there is no requirement for the recipient of the deposit to provide the results of utilization to the requester. There is a bonus to the requester, but the amount of the bonus is the authority of the Sharia banking management. 4 The knockout system in KSPPS BMT Lumbung Artho has been running for 3 periods since 2011. The implementation of the knockout system will be drawn every 1 month on the 15th, if it coincides with the red date or holiday, the draw will be postponed the next day for 36 rounds or 36 month. For members who have deposited arisan money at the time the round gets it, at the next round members no longer need to deposit. This knockout system has 500 members which will be drawn every 1 month. This knockout arisan deposit is Rp. 50,000,- In rounds 1 through 6 get savings and bonuses of Rp. 700,000,-, rounds 7 to 12 get savings and bonuses of Rp. 950,000,-, rounds 13 to 18 get savings and bonuses of Rp. $1,200,000,-$, round 19 to 24 get savings and bonuses of Rp. 1,450,000,- , rounds of 25 to 30 get savings and bonuses of Rp. 1,700,000,- rounds 31 to 36 get savings and bonuses of Rp. 1,950,000,- For members who have not yet drawn their draws, the 37th month will be distributed simultaneously in the form of Rp. 1,800,000,- plus a bonus money of $\mathrm{Rp}$. 150,000,- and can enter the main door prize draw in the form of refrigerators, TVs, bicycles, fans, etc. In accordance with the initial contract that the money deposited will be returned at

2 Mujiyatun, Ridawati . "Yad Amanah dan Yad Dhamanah (Telaah Konsep Penghimpunan Dana Pada Produk Sistem wa'diah)." TAFAQQUH Jurnal Hukum Ekonomi Syari'ah dan Ahwal Syahsiyah, 2016: 24-33 .

3 Sehani. "Analisis Persepsi dan Preferensi Masyarakat Pesantren Terhadap Bank Syari'ah (studi pada Masyarakat Pesantren D Kota Pekanbaru )." Jurnal Al- Iqtishad, 2017 : 1-18.

4 Harun. "Multi Akad Dalam Takaran Fiqih ." S U H U F, 2018 : 178-193.

Website: http://jurnal.radenfatah..ac.id/index.php/ieconomics 
the time of the draw or at the end, if not received the draw will be given in the thirty-seventh month (37) plus a bonus.

Based on the description above, we can understand that there are problems in the knockout system. The contract used by the BMT Lumbung Artho KSPPS uses the Wadi'ah yad Al-dhomanah contract which the money deposited by the arisan members is kept to be managed by the BMT, and basically the Wadi'ah contract should be kept by the depositor at any time. However, the agreement is not in accordance with the fatwa of the National Sharia Council of Indonesian Majlis Ulama about the nature of wadi'ah saving that deposits can be withdrawn according to the wishes of the depositors and not waiting for lottery numbers to take their deposits.

\section{LITERATURE REVIEW}

Arisan is the activity of collecting money or goods of the same value by several people then drawn among them to determine who gets it, the lottery is held in a periodic meeting until all members get it. The economic mutual cooperation activities in the form of arisan have actually been known by all Indonesian people. As implemented in several regions.5and in Madura, East Java.6 Many benefits can be obtained from arisan, such as the benefits of anonymity include 1) the collection of a sum of money in a larger nominal amount; 2) ease of non-interest and non-collateral loans (borg); and 3) with the existence of larger nominal funds, it is possible to be made capital capital in business development. In addition to economic benefits, the benefits of social gathering can also be seen in its social dimensions, such as 1) an increase in the intensity of communication between members; 2) the emotional ties of the group and the community of participants; 3) enable the spread of social access that is useful for forming and building social life. In addition to the arisan money, also known as actually arisan death, wedding arisan, sacrifice arisan and so forth.7

Such is the money arisan. In the community or in a smaller scope, family clan, there are economic agreements to hold the wedding of one of his family members. As for the

\footnotetext{
${ }^{5}$ Syafrida , Hafni Sahir. "Analisis Karakteristik Peserta Arisan Di Kota Medan, Sumatera Utara." Andalas Journal of Sociology , 2012: 103-116.

${ }^{6}$ Zaitur , Rahem . "Eksplorasi Prakti Ajaran Beragama Kelompok Arisan Sabellasan Desa Pajundan Daleman Guluk-Guluk." Kabilah Jurnal Of Social Community, 2016: 127-141.

7Syahril , Jamil . ""Arisan Mbangun" Perspektif Pola Kegotongroyongan Ekonomi pada Masyarakat Desa Sako Kabupaten Banyuasin ." NURANI Jurnal Kajian Syari'an dan Masyarakat, 2018 : 1-8.
}

Website: http://jurnal.radenfatah..ac.id/index.php/ieconomics 
procurement of bridal room equipment, equipment or household furniture, aisle, catering and so forth. This agreement can be in the form of cash or some are in the form of goods. Even in the last decade, new forms of arisan arising, namely arisan qur'ban Arisan in this context is the activity of collecting a sum of money, which is carried out monthly, weekly or even daily by a group of people with the aim of sacrificing on the Eid al-Adha holiday. Usually this type of social gathering group members consists of 7 people and applies multiples. At the time of Eid al-Adha, if the cycle of 7 people is not fulfilled, the sacrificial animals will be changed from cows to goats or cattle. Even online sacrificial social gathering has been done a lot, however the Indonesian Ulama Council (MUI) and the National Sharia Council (DSN) have not yet issued a fatwa specifically regulating transactions / trade electronically (online) or as we know it as e-commerce, but in jurisprudence.

The main principles that define shari'ah finance are, belief in divine guidance, usury cannot be imposed on any transaction, money is only invested for a noble cause, various risks are recommended among business partners, and financing must be based on real assets. These principles can be seen as activities that are prohibited and activities that are recommended. The principle of shari'ah means to stress that economic agents always uphold ethical and legal norms in economic activities in accordance with shari'ah. 8

Demand deposits are deposits which can be withdrawn at any time by g checks, crossed checks and other means of payment orders or by way of book-entry after fulfilling various specified conditions. In general, Islamic banks use the principle of al-wadiah yad dhamanah in a checking account 9. Al-Wadiah is a pure deposit from one party to another, both individuals and legal entities that must be maintained and returned whenever the requester wants. 10. Al-Wadiah is divided into two types namely al-wadiah yad dhamanah and al-wadiah yad amanah. Al-wadiah yad dhamanah is a deposit carried out in which the bank is responsible for the integrity of the deposited assets so that he may make use of the deposited assets. While alwadiah yad amanah is a deposit agreement which is carried out where the bank is not required to replace it if a calculation error occurs. In this case the treasure of

8 Syaeful , Bakhr. "Minat Mahasiswa Dalam Investasi Di Pasar Modal." AL-AMWAL Jurnal Kajian Ekonomi dan Perbankan Syari'ah, 2018 : 146-157.

9 Kelik , Mugiharjo, Dhiana Paramita Patricia , and Fathoni Aziz . "Analysis Of The Factor Affecting The Levels For Results Of Mudharabah Deposts In Sharia Commercial Bank In Indonesia Period 2013 -2017." Journal of Management, $2019: 1-8$.

10 Mohd, Sollehudin Shuib, A Bakar Azizi , F. Osmana Amirul, Hashima Hydzulkifli, and Bin Fadzil Aiman . "Implementation of Al-Wadiah (saving instrument)." Journal of Business, 2016 : 35-38. 
Islam teaches that in trying human beings should take the halal and thayib. Understanding halal can be seen in terms of material, how to obtain, how to use or use is not contrary to Islamic sharia one of which is developed by Islamic banks in Indonesia is the concept of demand deposits or deposit. Understanding wadi'ah can be interpreted as giving safekeeping to others to safeguard his property.11 The legal basis of the wadiah from Al-Quran and Hadith, in the An-Nisa verse verse 58 is explained

1. Al-Qur'an

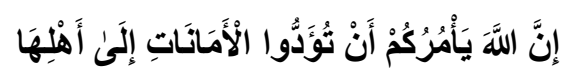

That means : " Verily Allah tells you to deliver the message (entrusted), to those who are entitled to receive it. (an-Nisaa': 58)

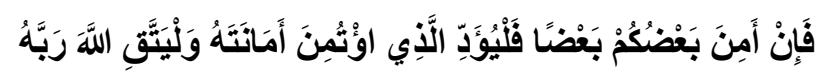

That means :" if some of you believe in others, let those who believe fulfill their mandate (their debt) and let them fear Allah their Lord". (al-Baqarah: 283)

2. Al-Hadits

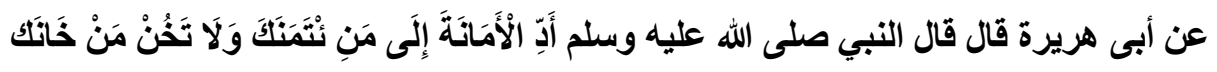

That means : Abu Hurairah related that Rasullulah saw. said, "Convey (deliver) the mandate to those who are entitled to receive it and do not repay treason to those who have betrayed you."( HR Abu Dawud and according to Tirmidhi this hadith hasan, while Imam Hakim categorized saheeh)

From these verses and hadith that the deposit or Wadiah is a mandate that must be carried by the recipient of the deposit and safeguard it until the deposit is taken again by the rightful.

3. Ijma'

Ijma 'is a reference after the Qur'an and Al-hadith, in this case the leaders of Islamic scholars throughout the ages have done ijma (consensus) on the legitimacy of al-Wadi'ah

${ }_{11}$ Riyanto, and Paramansyah Arman . "Pengaruh Giro Wadiah dan Mudharabah Terhadap Peningkatan laba (Surve Pada Bank Syari'ah Cabang Bekasi)." AL_HARAJ Jurnal Ekonomi, Keuangan \& Bisnis Syari'ah, 2019 : 81-91.

Website: http://jurnal.radenfatah..ac.id/index.php/ieconomics 
because human needs for this are clearly seen, as quoted by Dr. Azzuhaily in al-Fiqh alIslami wa Adillatuhu from the book al-Mughni wa Syarh Kabir li Ibni Qudhamah and Mubsuth li Imam Sarakhsy.12

One of the principles used by Islamic banks or other financial institutions in mobilizing funds is to use the principle of deposit. The contract that is in accordance with this principle is al-wadiah. Al-wadi'ah is a pure deposit which can be taken at any time if the owner wishes. The first pillar of the wadiah contract perpetrators, namely requester goods or assets (Muwaddi ') and the recipient of the deposit (mustawda'). The two Akada objects are items entrusted, the third Shigat is consent and qabul. Meanwhile, the condition of the first Wadi'ah bonus is a depositary (prerogative right) policy, the second bonus is not required in advance. 13

There are two types of Wadiah savings, namely Wadiah Yad Amanah and Yad Dhamanah. In general, wadiah is purely entrusted from the requester (muwaddi') that is given the trust or trust, both individuals and legal entities, the items deposited must be protected from damage, loss, security and integrity, and returned whenever the depositor wants to. In this case, the depositor (constodian) as the recipient of the trust (trustee) is yad al-amanah which means that he is not required to be responsible if during safekeeping there is loss or damage to the goods / assets deposited, besides that if the damage is not the result of negligence or storage carelessness. In this form, the depositor may not use or make use of the goods / assets deposited, but only safeguard them. In addition, the goods / assets that are entrusted must not be confused with other goods / assets, but must be separated for each item / assets of the depositor. Because it uses the principle or form of yad al-amanah, such deposit contracts are commonly called Wadiah yad Amanah .14

Of the type of yad adh-dhommah, which means the depositor is responsible for any damage or loss that occurs to the item or assets deposited. With this type, the depositor may mix the depositary assets with the depositary assets or other depositing assets. And then used for productive purposes for profit. The safekeeping party has the right to seek benefits derived from the use of entrusted assets and is fully responsible for the risk of losses that may

12 Shafi'ii, Abdul Azeez Bello, and BT Hassan Rusni . "Saving and Current Account In The Context Of syari'ah Contract." Arabian Juornal Of Business and management Review, 2014: 8-20 .

13 Fitriyani. Tinjauan Hukum Islam Terhadap Tabungan Wadi'ah ( studi pada PD BPR Syari'ah Ciligon Mandiri Banten). Banten : UIN Sultan Maulana hasanuddin, 2019.

14 Fitriyani. Tinjauan Hukum Islam Terhadap Tabungan Wadi'ah ( studi pada PD BPR Syari'ah Ciligon Mandiri Banten). Banten : UIN Sultan Maulana hasanuddin, 2019.

Website: http://jurnal.radenfatah..ac.id/index.php/ieconomics 
arise. In addition, depositors are also permitted to give bonuses to asset owners without prior agreement. 15

\section{RESEARCH METHODS}

This study uses qualitative research methods that use content analysis. The method used is the first Field Research, conducted by researchers to come directly to the research object to obtain a complete picture. Second Library Research, in the research library researchers examine references that are related to the object of research that is social gathering in the perspective of sharia.

\section{RESULT AND DISCUSSION}

In the implementation of the knockout arisan money system, the arisan agreement is made in writing, that is, the agreement has been written in a paper sheet that has been signed between the member and the KSPPS BMT Lumbung Artho and is not done one by one with the members of the arisan. As stated by Nurul Khafid, if a member agrees to the terms of the social gathering, members can join the social gathering. If a member does not agree with the existing provisions in the arisan agreement, the participant may not participate in the arisan. From this statement it can be concluded that the arisan agreement does not force the members of the social gathering. So that members who join social gathering based on their own desires.

Willingness (al-ridha) in arisan can be applied to each member, so that from the beginning to give up a fixed amount of money to be deposited to KSPPS BMT Lumbung Artho. Because without the willingness is impossible that this money arisan can be carried out. Transactions are also said to be valid if they are based on the pleasure of both parties. This means that a contract is not valid if one party is forced or forced. It can happen when the contract has willingness to pay to one another, but then one party feels burdened, so that it loses its faith, then the contract can be canceled. This was explained by Nurul Khafid as manager and secretary of the knockout system with answers because from the beginning before the implementation of the gathering it was notified to members participating in the gathering to give up the predetermined amount of money to be deposited for the social

15 Ahmad, Dahlan . "Two Tier Mudarabah di Bank Syariah: Transformasi Fikih dalam Bisnis." AlManahij , 2014: 95-108.

Website: http://jurnal.radenfatah..ac.id/index.php/ieconomics 
gathering, but if there were members who feel objected then are not forced to follow it. Willingness also fosters mutual cooperation among members where mutual cooperation has a positive effect to help one another.16

From this statement it can be concluded that the two parties have exchanged meridhai to hold a social gathering. Between members have agreed to deposit the social gathering money and the management will manage the social gathering money. The knockout system of money held by KSPPS BMT Lumbung Artho by fulfilling the elements. If the elements have not been fulfilled, they have not been said to be valid. As for the elements of the knockout money gathering system in KSPPS BMT Lumbung Artho, First Party who entrusts (Muwaddi') This element must be present in the arrangement of the fallout money gathering, therefore this element is very important. According to the principle of shari'ah arisan system of knockout money in KSPPS BMT Lumbung Artho or referred to as deposits (Wadi'ah) which have Muwadi 'and Mustawda'. Both parties must know each other because it involves the money deposited which will then be used by Mustawda' (the person who received the deposit). In the practice of this knockout system, the recipient of the deposit has not made good use because it is not transparent in its use, and the benefits from the use of the money are given to Muwaddi', but in the form of a bonus whose nominal amount has been determined at the beginning of the agreement. In the utilization of entrusted assets or the wadiah contract, it must be known to the person who entrusts both in terms of protecting his property either through the correct expression and actions or cues.17

Second, the manager (Mustawda'). The manager is a very important element in the social gathering, because the manager is the party that holds the social gathering activities and makes the social gathering agreement with the members who manage the social gathering funds. Arisan is also intended to manage household finances with the hope that income is sufficient for daily needs, for that arisan is interpreted as savings where the savings will be used as business capital. 18Third, Akad (Ijab and Qobul). The existence of a system of

16 Syahril , Jamil . ""Arisan Mbangun" Perspektif Pola Kegotongroyongan Ekonomi pada Masyarakat Desa Sako Kabupaten Banyuasin ." NURANI Jurnal Kajian Syari'an dan Masyarakat , 2018 : 1-8.

17 Adila, Rachmaniar Putri, and Abidah Suryaningsih Sri . "Analisis Kegiatan Arisan Dalam perspektif Islam Di Kelurahan Sememi Surabaya." Jurnal Ekonomika dan Bisnis Islam, 2018 : 55-65.

18 Pristiana, Widyastuti, Soeti Yani Ari , and Basuki Kustiadi . "Household Financial Management through Arisan for Saving and Lending Association in Kiarasari Village [Pengelolaan Keuangan Rumah Tangga melalui Peranan Arisan Simpan Pinjam di Desa Kiarasari]." proceeding of Community Development . Jakarta : Sampoerna University , 2019. 55-59. 
covenant or cash withdrawal system agreement will determine the arisan that has been carried out, both in terms of the amount of contributions, the period of withdrawal of cash withdrawal system, the implementation of the draw, and the number of members that have been determined along with the Wadi'aha Yad-Dhamanah contract therein. Fourth, the object of the contract (money). In Wadi'ah, which is used in the contract, it is clear and required to have both movable and immovable or tangible goods. In the practice of the system of arisan money collections with prizes, based on an agreement that has been agreed that the object of the contract (money) is deposited once every month for 36 months, the date that has been set is every 15 th of each month.

Fifth, Lottery Numbers are numbers that will be drawn at the time of the draw. The number belongs to the members of this knockout money gathering system. This number is in the form of a code and the drawing is ball. The sixth process of handing over money, this process is carried out directly to members of the social gathering who are lucky to get the lottery number, if not present then the lottery will be repeated until the person present, As said by the organizer of the social gathering. That the arisan money is directly handed over to the lucky members. So if it is not present, it will be drawn again until the number called is in question.

From the elements of the system of falling money gathering, the implementation of the fallout system of cash arising is binding on each party making the agreement. But basically Arisan is the activity of collecting money or goods of the same value by several people then drawn among them to determine who gets it, the draw is held in a meeting periodically until all members get it. (TPKPB, 2005:65).

However, it is different from social gathering in general with the knockout arisan which is carried out by KSPPS BMT Lumbung Artho. This was explained by Mr. Nurul Khafid as Manager, First, namely the collection of the same amount of money deposited by all members who joined the social gathering. Second, the draw is conducted once a month on the 15 th. For members of the social gathering who get the lottery are automatically canceled and have no obligation to pay the following month.

From the explanation, it can be concluded that the system of arisan money fall is different from the regular arisan, because members who have received the lottery then in the following month are not required to deposit again while arisan usually members must continue to deposit until the end of the draw.

Website: http://jurnal.radenfatah..ac.id/index.php/ieconomics 
The provisions and rules that exist in the fallout arisan money on depositing arisan funds amount is Rp. 50.000, - then the money is deposited and played or managed by KSPPS BMT Lumbung Artho, but basically the management is not transparent and is not open to arisan members. One member named Zainuddin said, who clearly did not know what the social gathering money would be made, the important thing would be to get so many social gathering money.

From this explanation it can be concluded that many members were not familiar with the mechanism and management of the arisan fund. Members only know the amount of money that must be deposited and only know the amount of the acquisition of social gathering money that has been determined at the beginning of the agreement. The profit from the funds will be realized in the form of a bonus of Rp. 650,000 and added to the money that has been deposited by members who get the draw in the first month. This was explained by Nurrohman Fauzan as the Shari'ah Supervisory Board regarding the basis for determining arisan bonuses every period, which is basically based on the results of calculations and has been calculated, the management or manager of the arisan fund does not want to harm members who take part in the arisan from beginning to end but indeed the acquisition is not as perfect as it gets. at the beginning. The overall benefits are not owned by individuals or individuals but for general benefit.

The Wadi'ah Yad-Dhamanah contract is assets or goods which are entrusted and may be utilized which means that the depositary is responsible for any damage or loss that occurs to the goods or assets deposited. This also means that the safekeeping party has obtained permission from the safekeeping party to use the goods or assets that are entrusted for certain economic activities, provided that the safekeeping party will return the goods or assets that are entrusted in full when the depositor wants him to take it and the owner can be given a bonus without pre-qualifying amounts. 19

From the explanation above, the researcher concludes that the arisan money collection conducted at KSPPS BMT Lumbung Artho Jepara is not fully in accordance with the Wadi'ah Yad-Dhamanah principle because in its implementation the arisan members only collect a certain amount of money that has been determined to be deposited every month.

19 Ahmad, Dahlan . "Two Tier Mudarabah di Bank Syariah: Transformasi Fikih dalam Bisnis." AlManahij, 2014: 95-108. 
Then, members who get a social gathering will be refunded the same amount of deposit. The deposit will be added to the bonus set out in the agreement by KSPPS BMT Lumbung Artho.

However, the arisan bonus giving does not reflect fairness to arisan members, because the acquisition of arisan bonuses given to members who get earlier is greater than members who get at the end of the 36th month as specified in the arisan attachment at the beginning of the contract. If the fallout money gathering is implemented using the Wadi'ah contract, which means it is a deposit, the longer the member keeps the money, then the profit sharing must be greater, not vice versa. From the bonuses that have been required, the nominal amount also does not reflect fairness because BMTs who have managed arisan money for a period can get a profit of approximately Rp. 80,000,000, - but only Rp. 150,000, one period is 3 years with a minimum number of 500 members while social gatherings are IDR 50,000 per member. This arisan is stored at the BMT office every time a member registers as a participant - this bonus comparison is very far from the profit sharing for 1 period. Meanwhile according to Mr. Drs. KH. Nurrohman Fauzan as the Shari'ah Supervisory Board at KSPPS BMT Lumbung Artho, the fall of the arisan system of money is more directed to Maysir, because the overall benefits should not be owned by individuals or individuals in this case the BMT, whereas in fact the results of the overall benefits can be utilized by all members for the benefit of together in this case both from the members of the social gathering or the organizer or BMT. Justice in giving bonuses can also be interpreted by the increasing contribution of arisan participants, the more bonuses he receives, for example the head of the member gets a lot of bonuses for contributing by finding many members.20

The use or management of the arisan money is not transparent and open to members of the arisan and is also not explained at the beginning of the contract. Many members do not understand the use of the Wadi'ah Yad-Dhamanah contract. And its application to the arisan mechanism with the Wadi'ah contract is not yet fully in accordance with the general provisions stipulated by the National Sharia Council Fatwa NO: 02 / DSN-MUI / IV / 2000 concerning wadi'ah savings. In this knockout money gathering member who has not yet gotten his lottery number, then he has not been able to get or take the deposit money until the preiode ends, meaning that for a period of three years who get the draw only 36 people, and

${ }^{20}$ Zumei, Intansari. Arisan? Studi Akad dan Bonus Pada Arisan Mapan di Kota Batu. Thesis, Malang : Universitas Islam Negeri Malang, 2019.

Website: http://jurnal.radenfatah..ac.id/index.php/ieconomics 
the money that has been collected will be given to participants arisan in the 37th month for those who did not get the draw and be rewarded bonus according to the initial agreement. However, if it is associated with a wadi'ah contract, the deposit money deposited by the member can be taken at any time if the member wants it.

Furthermore, in the awarding of bonuses, in this knockout money gathering bonuses have been set or required at the beginning of an agreement by the KSPPS BMT Lumbung Artho with a nominal amount of bonuses. However, if it is associated with a wadi'ah contract, the bonus given to the members is the nominal amount is not determined or required, because it is voluntary on the part of the BMT. In addition, fair bonuses must be in accordance with the contributions of members who are given for the benefit of social gathering.21If the arisan member does not pay the arisan deposit at the due date then it is not included in the draw. As explained by Mr. Nurul Khafid as Manager "Members who have not paid arisan deposits for 3 times in a row will be subject to a penalty and declared disqualified and then removed from the members of the social gathering, but the deposit money will still be returned the amount of money that was deposited during the social gathering and returned at the end of the 37th month period ".

In this case it can be concluded that the members of the social gathering do not fulfill the agreement that has been written in the provisions. The basis of all contracts in sharia principles is the perfection of the contract, so it is obligatory for each member to fulfill their promises. A contract that might be said to be sharia here can use the Al-qardh (credit) and Mudharabah agreements. Al-qardh contract (credit) or loan agreement. This term is known as a qardh contract, the lender (creditor) by providing loans to other parties on condition that the loan recipient will return the loan at the time agreed upon with the same amount when the loan was given without any additional. In essence al-qardh is a form of help and affection for borrowers who will feel the benefits for those who borrow. This form of contract contains a high level of human value both for the borrower and for the lender because it contains an element of mutual trust with each other. 22 Mudharabah or investment agreement is a contract to give money to a person in business so that he gets a percentage of profit. Where mudhorobah contracts are profit sharing agreements when the owner of the

21 Syahril , Jamil . ""Arisan Mbangun" Perspektif Pola Kegotongroyongan Ekonomi pada Masyarakat Desa Sako Kabupaten Banyuasin ." NURANI Jurnal Kajian Syari'an dan Masyarakat , 2018 : 1-8.

22 Rukiah, Implementasi Sifat Ta'awun Dalam Lembaga Keuangan Syariah Melalui Akad Al-Qardh.” Studi Multidisipliber, 2019: 87-102.

Website: http://jurnal.radenfatah..ac.id/index.php/ieconomics 
funds or capital is called shahibul maal, the provider of capital is called mudharib. The purpose of this agreement is to seek profit where the distribution depends on the agreement established between Shahibul Maal and Mudharib.23

\section{CONCLUSION}

The implementation of the fallout arisan money system is not yet fully in accordance with the existing sharia principles, and in terms of its muamalah it is also less open with the members of the arisan regarding the management of the arisan money. This knockout arisan money system is also not in accordance with the principle of fairness, because the acquisition of arisan bonus given to members who get earlier is greater than members who get at the end of the 36th month as specified in the attachment of the arisan when the contract is initiated. If the fallout money gathering is implemented using the Wadi'ah contract, which means it is a deposit, the longer the member keeps the money, then the profit sharing must be greater, not vice versa. The application of the wadi'ah contract is also not fully in accordance with the provisions of the National Shariah Council Fatwa because the nature of wadi'ah savings is that it can be taken at any time if the member wants it, but in this social gathering members must wait if they have obtained the lottery number. Giving a social gathering bonus is also not in accordance with the covenant of the wadi'ah, because it is voluntary. However, in this fall system of arisan money, the bonuses have been set up at the beginning of the agreement.

Another use of a contract that may be used in a knockout arisan is closer to the principles of sharia in order to avoid Gharar and Maysir. However, this contract has not yet fully become an appropriate reference. Because in the DSN-MUI there are no regulations regarding the withdrawal of the arisan system of money. The contract used is Al-qardh (debts) and Mudharabah. However, all applicable regulations and provisions must be changed by following the provisions in the National Sharia Council Fatwa No: 19 / DSN-MUI / IV / 2001 concerning Al-Qardh and the National Sharia Council Fatwa No. 115 / DSN-MUI / IX / 2017 concerning Mudharabah Agreements.

23 Firda, Izzati Febriani. "Pengaruh Tingkat Bagi Hasil, Financing to Deposit Ratio (FDR) Dan Tingkat Inflasi Terhadap Deposito Mudharabah Pada Bank Umum Syariah (BUS) Periode 2014 - 2017." Jurnal Ekonomi Syari'ah , 2019 : 108- 118 . 


\section{REFERENCES}

Adila, Rachmaniar Putri, and Abidah Suryaningsih Sri . "Analisis Kegiatan Arisan Dalam perspektif Islam Di Kelurahan Sememi Surabaya." Jurnal Ekonomika dan Bisnis Islam, 2018 : 55-65.

Afif, Mufti. "Tabungan Implementasi Akad Wadiah atau Qord Kajian Peraktek Wadiah di Perbankan Indonesia." Jurnal Hukum Islam , 2014 : 251-264.

Ahmad , Dahlan . "Two Tier Mudarabah di Bank Syariah: Transformasi Fikih dalam Bisnis." Al-Manahij , 2014: 95-108.

Firda, Izzati Febriani. "Pengaruh Tingkat Bagi Hasil, Financing to Deposit Ratio (FDR) Dan Tingkat Inflasi Terhadap Deposito Mudharabah Pada Bank Umum Syariah (BUS) Periode 2014 - 2017." Jurnal Ekonomi Syari'ah , 2019 : 108- 118.

Fitriyani. Tinjauan Hukum Islam Terhadap Tabungan Wadi'ah ( studi pada PD BPR Syari'ah Ciligon Mandiri Banten). Banten : UIN Sultan Maulana hasanuddin , 2019.

Harun. "Multi Akad Dalam Takaran Fiqih ." S U H U F, 2018 : 178-193.

Kelik, Mugiharjo, Dhiana Paramita Patricia, and Fathoni Aziz . "Analysis Of The Factor Affecting The Levels For Results Of Mudharabah Deposts In Sharia Commercial Bank In Indonesia Period 2013 -2017." Journal of Management, 2019 : 1-8.

Mohd, Sollehudin Shuib, A Bakar Azizi , F. Osmana Amirul , Hashima Hydzulkifli, and Bin Fadzil Aiman . "Implementation of Al-Wadiah (saving instrument)." Journal of Business, 2016 : 35-38.

Mujiyatun , Ridawati . "Yad Amanah dan Yad Dhamanah (Telaah Konsep Penghimpunan Dana Pada Produk Sistem wa'diah)." TAFAQQUH Jurnal Hukum Ekonomi Syari'ah dan Ahwal Syahsiyah, 2016: 24-33 .

Pristiana, Widyastuti, Soeti Yani Ari , and Basuki Kustiadi . "Household Financial Management through Arisan for Saving and Lending Association in Kiarasari Village [Pengelolaan Keuangan Rumah Tangga melalui Peranan Arisan Simpan Pinjam di Desa Kiarasari]." proceeding of Community Development . Jakarta : Sampoerna University , 2019. 55-59.

R, Noviati . "The Practice Of Kurban Online In The Perspektif Of Islam In Tebar." Syarikah Jurnal Ekonomi Islam , 2017 : 143-357.

Republik , Indonesia , and Agama Departemen . Al-Quran dan Terjemahanya. Bandung, 2015.

Riyanto, and Paramansyah Arman . "Pengaruh Giro Wadiah dan Mudharabah Terhadap Peningkatan laba (Surve Pada Bank Syari'ah Cabang Bekasi)." AL_HARAJ Jurnal Ekonomi, Keuangan \& Bisnis Syari'ah, 2019 : 81-91.

Website: http://jurnal.radenfatah..ac.id/index.php/ieconomics 
Rukiah, Implementasi Sifat Ta'awun Dalam Lembaga Keuangan Syariah Melalui Akad AlQardh.” Studi Multidisipliber, 2019: 87-102.

Sehani. "Analisis Persepsi dan Preferensi Masyarakat Pesantren Terhadap Bank Syari'ah (studi pada Masyarakat Pesantren D Kota Pekanbaru )." Jurnal Al- Iqtishad, 2017 : 118.

Shafi'ii, Abdul Azeez Bello, and BT Hassan Rusni . "Saving and Current Account In The Context Of syari'ah Contract." Arabian Juornal Of Business and management Review, 2014: 8-20.

Syaeful , Bakhr. "Minat Mahasiswa Dalam Investasi Di Pasar Modal." AL-AMWAL Jurnal Kajian Ekonomi dan Perbankan Syari'ah, 2018 : 146-157.

Syafrida , Hafni Sahir. "Analisis Karakteristik Peserta Arisan Di Kota Medan, Sumatera Utara." Andalas Journal of Sociology, 2012: 103-116. 